\title{
A new species of the trapdoor spider genus Ummidia Thorell, 1875 (Aranei: Ctenizidae) from Afghanistan
}

\author{
Новый вид пауков-землекопов рода Ummidia Thorell, 1875 \\ (Aranei: Ctenizidae) из Афганистана
}

\author{
S.L. Zonstein \\ C.А. Зонштейн \\ Department of Zoology, The George S. Wise Faculty of Life Sciences, Tel-Aviv University, 69978 Tel-Aviv, Israel. E-mail: znn@post.tau.ac.il \\ KEY WORDS: Burrowing spiders, Mygalomorphae, ctenizids, taxonomy, Central Asia. \\ КЛЮЧЕВЫЕ СЛОВА: Норные пауки, Mygalomorphae, ктенизиды, таксономия, Центральная Азия.
}

ABSTRACT. Ummidia mischi sp.n. is described from the three males collected from south Afghanistan (Kandagar). The new species can be distinguished from the closest congener U. ganjinoi (Andreeva, 1968) by the noticeably narrower carapace, the more widely spaced anterior median eyes, the longer palpal tibia and details of the distal part of embolus.

РЕЗЮМЕ. Ummidia mischi sp.n. описывается по трем самцам из Южного Афганистана (Кандагар). От ближайшего вида, U. gandjinoi (Andreeva, 1968), новый вид отличается заметно более узким карапаксом, шире расставленными передними медиальными глазами, более длинной голенью педипальпы и деталями строения дистальной части эмболюса.

\section{Introduction}

The trap-door spider genus Ummidia Thorell, 1875 is known to include 25 species, of which the majority (20) are distributed in the Americas, from southern USA to Venezuela [Platnick, 2014]. Four representatives are confined to the Western Mediterranean [Decae, 2010]. The only isolated species is known to occur in entire Central Asia, particularly in Tajikistan [Andreeva, 1968, 1976; Zonstein, 2008]. Such the unusual distributional pattern testifies to the fact that the genus certainly is in need of a comprehensive taxomic revision. New material recently collected from Afghanistan allows me to discover a new species of the genus; its diagnosis and description are provided below. The holotype and one of the paratypes have been deposited in the Department of Zoology of the Tel-Aviv University, Israel (TAU); the third paratype has been placed to the Zoological Museum of Moscow University (ZMMU).

All measurements are given in millimeters (for eyes they are also given in parentheses, when include or count tapetum). The abbreviations used in the text are as follows: a - apical; ALE - anterior lateral eyes; AME anterior median eyes; $\mathrm{d}$ - dorsal; $\mathrm{p}$ - prolateral; $\mathrm{pd}$ - prodorsal; PLE - posterior lateral eyes; PLS - posterior lateral spinnerets; PME, median lateral eyes; PMS posterior median spinnerets; $\mathrm{pv}$ - proventral; $\mathrm{r}$ - retrolateral; rd — retrodorsal; rv — retroventral; v — ventral.

\section{Description}

Ummidia mischi sp.n.

$$
\text { Figs 1-6. }
$$

TYPES. Holotype $O^{7}$ (TAU) from Afganistan, the vicinity of Kandagar, April 2012, coll. M. Misch. Paratypes: together with the holotype: $2 O^{7} O^{7}$ (TAU \& ZMMU).

ETYMOLOGY. The species is named after Michael Misch who collected the type series.

DIAGNOSIS. By many characters including the pedipalp shape and the bulb conformation, the new species resembles $U$. gandjinoi (Andreeva, 1968), but can reliably be distinguished from it by the noticeably narrower carapace, the more widely spaced anterior median eyes, the longer palpal tibia and the less curved and more tapering embolus (cf. Figs 2-3, 5-6 and Figs 1-3 in Andreeva [1976]). Besides, the males of $U$. mischi sp.n., with the carapace length of 6.20-6.90 $\mathrm{mm}$, are noticeably smaller than the male holotype of $U$. gandjinoi (the carapace length $9.80 \mathrm{~mm}$ ).

MALE (holotype). Habitus as in Fig. 1. Body length including chelicerae 13.75.

Coloration in alcohol: carapace and chelicerae very dark reddish brown, palps and legs reddish brown except for lighter coloured palpal tibia, cymbium, metatarsi and tarsi III-IV; sternum, labium and abdomen ventrally yellowish brown; abdomen dorsally dark brown, with spotted light brown pattern; genital area, book-lungs and spinnerets brownish yellow.

Carapace (Fig. 2): 16.20 long, 6.02 wide. Eye group on a low tubercle, arranged as shown in Fig. 3. Eye diameters: AME 0.19 (0.27), ALE 0.33, PLE 0.27, PME: 0.20. Interspaces: AME-AME 0.20(0.08), ALEAME 0.23(0.19), ALE-PLE 0.26, PLE-PME 0.09, PME-PME 0.50 . 

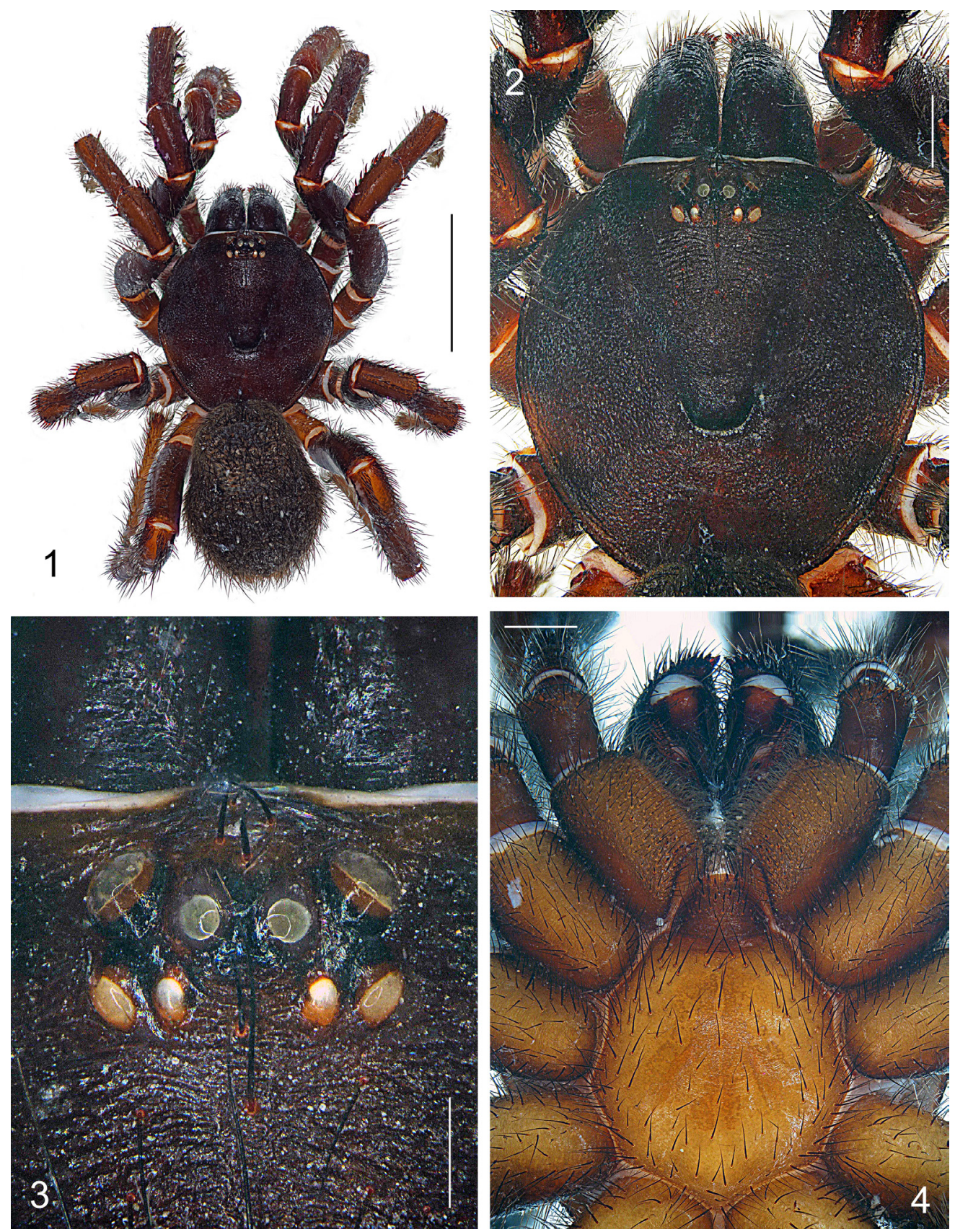

Figs. 1-4. Ummidia mischi sp.n., male holotype: 1 - habitus, dorsal view; 2 - carapace and chelicerae dorsal view; 3 - eye tubercle dorsal view; 4 - sternum, labium, chelicerae, maxillae and leg coxae ventral view. Scale bars: $1-5.0 \mathrm{~mm}, 2,4-1.0 \mathrm{~mm}, 3-0.5 \mathrm{~mm}$.

Рис. 1-4. Ummidia mischi sp.n., самец голотип: 1 - общий вид паука, вид сверху; 2 - карапакс и хелицеры, вид сверху; 3 глазной бугорок, вид сверху; $4-$ стернум, лабиум, хелицеры, максиллы и коксы ног, вид снизу. Масштаб: $1-5,0$ мм, $2,4-1,0$ мм, $3-0,5$ мм.

Chelicerae: furrow with 5-6 promarginal and 6-7 retromarginal teeth; rastellum consists of $40-45$ stout cone spines on mound; fang in medial part almost indistinctly serrate.

Labium (Fig. 4): trapezoidal; 0.89 long, 1.30 wide; with 9 cone cuspules.

Maxillae: with 9-10 cone cuspules; mostly confined to probasal maxillary edge.
Sternum: 3.51 long, 3.35 wide. Sternal sigilla confluent.

Palp (Figs 5-6). Bulb pyriform. Embolus long thin, tapering and slightly curved.

Legs with numerous spines, thornlike on patellae and tibiae; but all femora, patella IV, tarsi I, II and IV, and whole pedipalp aspinose. Leg I: patella p1-1-1-1, pv1-1, r1-1(2); tibia pv10-15, rv8-10; metatarsus pv1- 

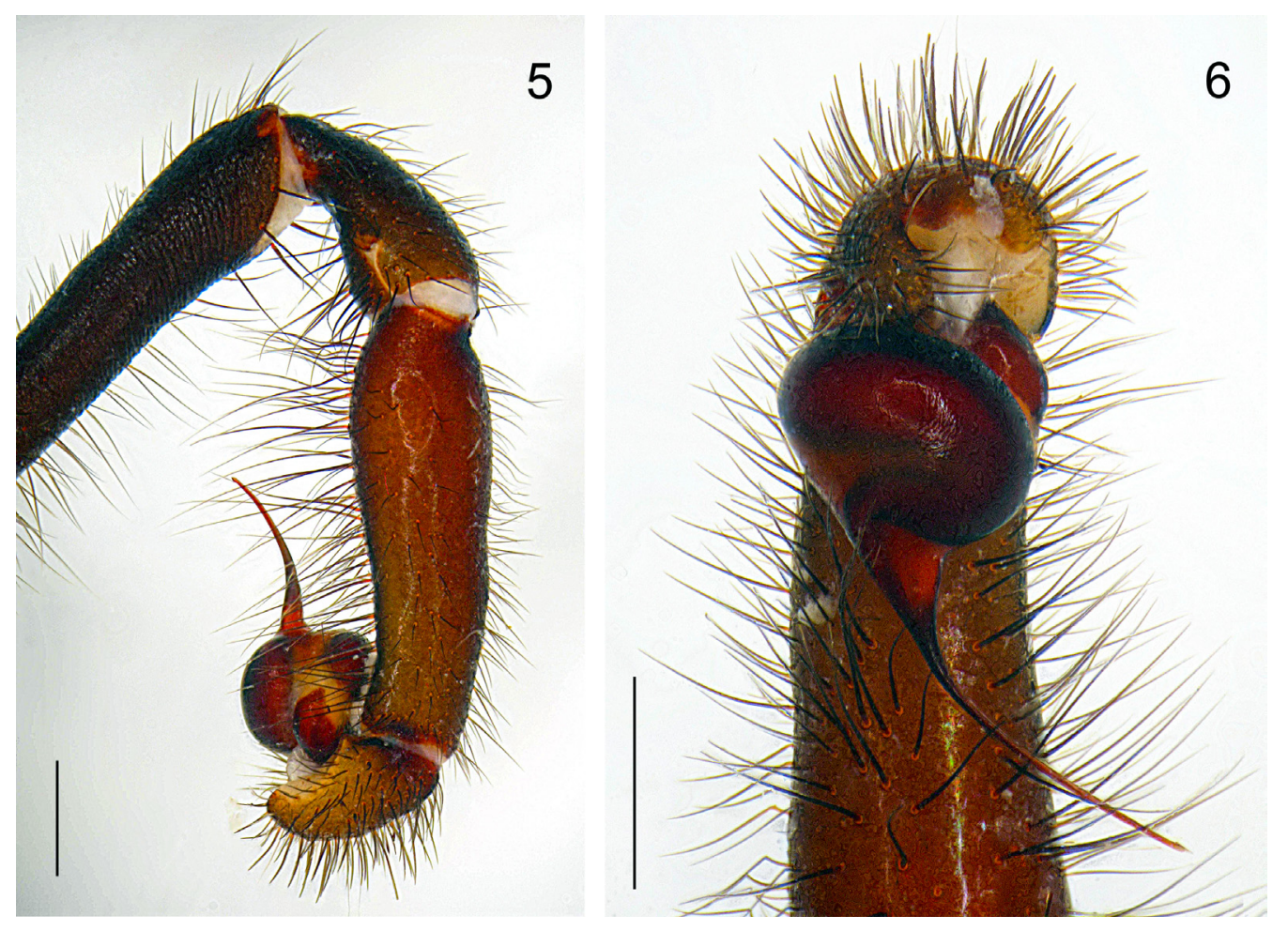

Figs. 5-6. Ummidia mischi sp.n., male holotype, distal segments of the pedipalp, the bulb and the embolus: 1 - retrolateral view; 2 ventral view. Scale bar $1.0 \mathrm{~mm}$.

Рис. 5-6. Ummidia mischi sp.n., самец голотип, дистальные сегменты педипальпы, бульбус и эмболюс: 1 - вид сбоку (снаружи); 2 - вид снизу. Масштаб 1,0 мм.

1-1-1, rv1-1. Leg II: patella p1-1-1-1, pv1-1, r1-1; tibia pv7-8, rv3a; metatarsus pv1-1-1, rv1-1. Leg III: patella $\mathrm{d} 2-1-1-4, \mathrm{p} 1-1-2-4, \mathrm{r} 1-1$; tibia $\mathrm{p}-\mathrm{pd} 7 \mathrm{a}, \mathrm{r}-$ rd6(7)a, v1-3a; metatarsus v1-3(4)a; tarsus v4(5). Leg IV: tibia pv1-2-1-2; metatarsus pv1-1-1-3, rv1a. Tarsi and distal metatarsi I-II with entire, short but dense scopula. Trichobothria: 2 rows of 4-6 per row on tibiae; 7-10 on metatarsi; about $20(+3-5$ clavate trichobothria on legs I-II) on tarsi. Tarsal claws: paired claws I-IV with 1 large and acute proximal tooth, unpaired claw steeply curved, bare. Leg and palp measurements:

\begin{tabular}{|l|c|c|c|c|c|}
\hline & Palp & I & II & III & IV \\
\hline Femur & 4.02 & 5.27 & 4.73 & 4.17 & 5.48 \\
\hline Patella & 2.03 & 2.47 & 2.33 & 2.15 & 2.47 \\
\hline Tibia & 3.64 & 3.39 & 2.73 & 2.44 & 3.28 \\
\hline Metatarsus & - & 2.92 & 2.48 & 2.49 & 3.83 \\
\hline Tarsus & 1.31 & 1.38 & 1.40 & 1.86 & 2.25 \\
\hline Total & 11.00 & 15.43 & 13.67 & 13.11 & 17.31 \\
\hline
\end{tabular}

FEMALE. Unknown.
ACKNOWLEDGEMENTS. I wish to thank Michael Misch (Germany) who kindly provided me with his spider material. This study has been possible thanks to the financial help providing generously by stuff members of the Ministry of Absorption, Israel.

\section{References}

Andreeva E.M. 1968. [Materials to the spider fauna of Tadzhikistan. III. Mygalomorphae] // Dokl. AN Tadzh. SSR. Vol.11. No.7. P.68-71 [in Russian]

Andreeva E.M. 1976. [Spiders of Tajikistan]. Dushanbe: Donish. 195 p. [in Russian]

Decae A.E. 2010. The genus Ummidia Thorell 1875 in the western Mediterranean, a review (Araneae: Mygalomorphae: Ctenizidae) // J. Arachnol. Vol.38. P.328-340.

Platnick N.I. 2014. The world spider catalog, version 14.5. American Museum of Natural History, online at: http://research.amnh. org/iz/spiders/catalog.

Zonstein S.L. 2008. Description of the female of the Central Asian trapdoor spider Ummidia gandjinoi (Andreeva, 1968) (Aranei: Ctenizidae) // Arthropoda Selecta. Vol.16. No.3. P.150-151.

Responsible editor D.V. Logunov 